\title{
DEVELOPING DYNAMIC CAPABILITIES TO SURVIVE A CRISIS: TOURISM ORGANISATIONS' RESPONSE TO CONTINUED TURBULENCE IN LIBYA
}

\author{
Dr Hafez E.L Mansour \\ Department of Management \\ University of Tobruk \\ Professor Kirsten Holmes * corresponding author \\ School of Marketing \\ Curtin University \\ Dr Bella Butler \\ School of Management \\ Curtin University \\ Associate Professor Subramaniam Ananthram \\ School of Management \\ Curtin University
}

\section{INTRODUCTION}

The dynamic capabilities view has evolved significantly since its first (Eisenhardt \& Martin, 2000; Teece, Pisano, \& Shuen, 1997) and has become one of the most commonly used theoretical approaches in management research (Schilke, Hu, \& Helfat, 2016). Scholars have noted the specific importance of dynamic capabilities in fast-moving environments (Frank, Güttel, \& Kessler, 2017; Girod \& Whittington, 2017). Global crises, natural disasters, ever-increasing competition and new technological developments challenge firms to respond to environmental change to enable them to survive and sustain their operations. The greater the environmental dynamism in a firm's environment, the more important its ability is to sense opportunities and threats and to reconfigure its 
resource capabilities by developing and applying dynamic capabilities. Many scholars acknowledge that a dynamic environment forces firms to develop dynamic capabilities to reconfigure their resources to cope with continuous change (Di Stefano et al, 2010; Easterby-Smith, Lyles, \& Peteraf, 2009; Frank et al., 2017; Vogel \& Güttel, 2013). While there is a significant research stream on dynamic capabilities, including empirical studies investigating the impact of the environment and the role of dynamic capabilities in medium-sized companies (e.g., Frank et al., 2017; Girod \& Whittington, 2017; Protogerou et al, 2012; Schilke, 2014), the question regarding which dynamic capabilities enable firms to survive in turbulent environments that threaten firms' existence remains unanswered. Our study extends the debate on the importance of dynamic capabilities in turbulent climates and focuses on firms' responses to environmental dynamism embedded within such turbulence to ensure their survival. Our research question is as follows: what dynamic capabilities are required to survive a military crisis and the following unrest?

Our study was conducted in a unique research context - a tourism market suffering from the consequences of civil war and the subsequent crisis. While recent studies have acknowledged that many tourism destinations experience ongoing crises (Backer \& Ritchie, 2017; Elshaer \& Saad, 2017; Ivanov, Gavrilina, Webster, \& Ralko, 2017) and tourism firms do continue to operate under such conditions (Orchiston, Prayag, \& Brown, 2016), those studies investigated turbulence predominantly caused by natural disasters. The implications of natural disasters for global tourism destinations are well documented in the literature (Mair, Ritchie, \& Walters, 2016; Pforr \& Hosie, 2008); however, analysis of the impact of military conflicts and the subsequent unrest on firms in traditional tourism markets is limited to journalists' reports. Research on tourism crisis recovery is mainly concerned with 
marketing and media management during the crisis and its aftermath (Avraham, 2015;

Beirman, 2003). Most of those studies have been conducted at the destination level (Boukas \& Ziakas, 2013; Gkritzali, 2017; Hajibaba, Boztuğ, \& Dolnicar, 2016), with few studies investigating how individual tourism organisations, which are often small enterprises with limited resources, respond to such crises and survive in these turbulent business environments (Dahles \& Susilowati, 2015; Orchiston et al., 2016).

The chosen context of our study is the tourism sector in Libya after the Arab Uprising crisis. The Arab Spring that swept through the Middle East and North Africa (MENA) region from 2010-2011, brought about great political turbulence, was followed by a marked decline in the number of international tourist arrivals. The Libyan civil war in 2011 halted tourism activities and paused the development of Libya's tourism sector (UNWTO, 2012). Ongoing hostilities and a turbulent environment in Libya resulted in international airlines and cruise ship companies stopping their operations in Libya. The number of international tourist arrivals dropped from 271,000 in 2010 to approximately 26,000 in 2011 (Lanquar, 2012). Since 2012, the numbers have fluctuated depending on the security situation in the country (Lanquar, 2015); Libya is expected to attract just 82,000 international tourist arrivals in 2017 (WTTC, 2017); more recent tourist arrival figures are unavailable. However, the majority of international tourist arrivals in Libya in 2011 were journalists and media workers, government and non-government activists and advocates for the Libyan revolution. The international tourist arrivals in 2012 and 2013 were mainly businessmen who came for business purposes/trips and not for leisure purposes (Lanquar, 2015; UNWTO, 2012, 2013, 2014). 
The civil war and ongoing unrest have resulted in the Libyan tourism infrastructure being partially destroyed, and the travel and tourism competitiveness index of Libya has significantly decreased from 3.74 to 3.2 (WEF, 2012). In fact, Libya was chosen as a research focus because its tourism industry has the potential to be Libya's second largest industry (after the oil industry), as the country boasts UNESCO world heritage sites, sea resorts and desert tourism (KPMG, 2014). In this particular case, the Secretary-General of the UN World Tourism Organisation (UNWTO) said that the Arab Spring provided a unique tourism opportunity for Libya and offers future growth prospects (Canty, 2011; Fick, 2007). Indeed, tourism organisations form the main part of the Libyan tourism industry and play a key role in future growth prospects, therefore it is important to investigate how tourism organisations survived a crisis and what organisational capabilities enabled them to achieve it..

We contribute to the debate on the relevance of dynamic capabilities under conditions of environmental turbulence by identifying which dynamic capabilities enabled tourism firms to survive in crisis conditions. We begin with a review of the literature on the role of dynamic capabilities in conditions of environmental turbulence and crisis management in the tourism sector.

\section{THEORETICAL DEVELOPMENT}

\subsection{Dynamic capabilities}

The dynamic capabilities view emerged as an extension of the resource-based view (Barney, 1991), which seeks to identify which resources are most important to a firm, and 
has attracted the attention of scholars and practitioners alike for its value in reconfiguring a firm's resource base in response to environmental change (Teece, 2014; Wilden \& Gudergan, 2017). Studies indicate that by developing dynamic capabilities, firms are able to respond to fast-moving, competitive and turbulent business environments (EasterbySmith et al., 2009; Eisenhardt \& Martin, 2000). Recent years have witnessed increased attention to dynamic capabilities in the literature on knowledge management and organisational learning, where dynamic capabilities are considered a means to accelerate the process of R\&D and innovation in firms (Babelyte-Labanauskè \& Nedzinskas, 2017; Tchuta \& Xie, 2017). The critical role of dynamic capabilities was emphasised by scholars investigating environmental dynamism who explore the relationships between dynamic capabilities and a firm's performance (Girod \& Whittington, 2017). Scholars studying dynamism argue that when the environment in which firms operate requires firms' capabilities to survive and grow, firms tend to develop rapidly (Ruiz-Ortega \& PattaRequena, 2013).

Tourism firms frequently operate in highly competitive and changeable environments - a feature of turbulent environments - and the dynamic capabilities view was also studied in the context of the tourism sector (Camisón \& Monfort-Mir, 2012; Leonidou, Leonidou, Fotiadis, \& Aykol, 2015). A recent study introduced the dynamic capabilities perspective as a means for tourism businesses to convert resources into competitive advantage (Otengei, Bakunda, Ngoma, Ntayi, \& Munene, 2017). Studying dynamic capabilities in specific local contexts helps to understand how firms access the knowledge embedded in these contexts to find solutions during critical national conditions (Nonaka, Hirose, \& Takeda, 2016). Access to external sources of information and the 
ability to respond to identified changes are especially important for effectively assessing and dealing with critical external conditions when firm survival is in question (Nonaka et al., 2016; Otengei et al., 2017).

Dynamic capabilities enable firms to initiate the process of repositioning themselves in the environment in which they operate and create new value (Lessard, Teece, \& Leih, 2016; Teece, 2007; Teece et al., 1997). Scholars representing a knowledge-based perspective on the development of dynamic capabilities emphasise the two important aspects of dynamic capabilities, namely, adaptive and creative capabilities (Nonaka et al., 2016). As Nonaka (1994, p. 14) argues, "any organisation that dynamically deals with a changing environment ought not only to process information efficiently (to be adaptive) but also create information and knowledge (to be creative)." While the process of interaction between adaptive and creative capabilities is well studied in the context of changing market conditions, the specific types of dynamic capabilities in conditions of market survival remain unexplored. This paper seeks to identify the types of dynamic capabilities that are necessary for firms' survival in an ongoing crisis.

\subsection{Tourism crises}

There is an extensive literature on tourism crises and disasters, particularly studies that seek to document and explain how tourism businesses and destinations respond to these crises (Avraham, 2015; Beirman, 2003; Bingjie, Pennington-Gray, \& Klemmer, 2015; Chen, 2011; del Mar \& Bremser, 2013; Henderson, 2007; Roach \& Kemish, 2006; Tse, So, \& Sin, 2006). While many crises take place over a short timeframe, after which the destination can 
work towards recovery, some crises, such as armed conflicts, are ongoing, creating a lengthy period of uncertainty.

The MENA region has experienced ongoing turbulence for decades. Morakabati (2013) examines tourism activity in the UNWTO Middle East region from 1950 to 2010 and reveals that the ongoing political instability resulting from a series of armed conflicts, as well as acts of terrorism, has been responsible for stalling the growth of international tourist arrivals to the region. These conflicts have distracted governments' attention from supporting and helping tourism enterprises, resulting in fragile tourism sectors across the region (Morakabati, 2013). The relative absence of studies examining the impacts of political and military crises on tourism in the MENA region before and after the Arab Spring Revolution in 2010-2011 is an important research gap in our understanding of these crises and MENA tourism firms' responses, especially at the firm level, to ongoing environmental turbulence.

Extant research on how tourism businesses and destinations respond to crises examines marketing communication, cost reduction, making tourists feel safe, improving the product and government support for the destination (Bingjie et al., 2015; Chen, 2011; Hajibaba et al., 2016; Henderson, 2007; Roach \& Kemish, 2006; Tse et al., 2006). In the immediate aftermath of a crisis, the focus is typically on managing global media networks, public relations strategies and press conferences, which play a significant role in offering reassurance, restoring image and enhancing reputation overseas to stimulate bookings (Beirman, 2009).

Most studies focus on the destination level response rather than on individual tourism firms (Mansour, 2016). A small number of studies examine how individual 
businesses respond to crises. During the 2001 foot and mouth crisis in the UK (Ritchie, Dorrell, Miller, \& Miller, 2004), various hospitality establishments used social media for crisis communication and corrective action as well as for providing updates to employees, hotel guests, the general public and other stakeholders (Bingjie et al., 2015; Ritchie et al., 2004). Other studies examine how small tourism firms responded to the foot and mouth disease and SARS crises (Irvine \& Anderson, 2004; Tse et al., 2006) and found that their immediate reactions were to reduce expenditures and costs and change their product mix. del Mar and Bremser (2013) show that the Spanish hospitality sector countered the fall-out from the 2007 global financial crisis by improving hotel characteristics, including high quality services and products, strong brand image; developing a loyal customer base and increasing spending on marketing. All of these characteristics improved financial performance in the crisis periods and their aftermath.

Researchers examining tourism restoration after crises and disasters (Blackman \& Ritchie, 2008; Mair et al., 2016; Santana, 2004) have identified the importance of organisational learning in the tourism recovery or resolution phase of the tourism crisis process. In the resolution stage of a tourism crisis, the ability of tourism businesses or destinations to learn from crises plays a role in developing an effective proactive planning and prevention strategy to improve tourism services and products to attract tourists back and form collaborative networks among stakeholders (Mair et al., 2016).

Recent studies highlight the impact of ongoing conflicts and tourism crises, including the refugee crisis after the Arab Spring and/or Arab Uprisings, ongoing political instability and terrorist attacks in the region, on tourism in MENA countries, such as Egypt, Jordan and Turkey and other developing countries, including Indonesia and Ukraine 
(Afonso-Rodríguez, 2017; Dahles \& Susilowati, 2015; Elshaer \& Saad, 2017; Ivanov et al., 2017). In Egypt, the long period of political unrest has led hotels and travel agents to adopt downsizing strategies by reducing the number of employees (Elshaer \& Saad, 2017). This approach has led to feelings of job insecurity among survivors and itself become a serious risk for the Egyptian tourism industry (Elshaer \& Saad, 2017). In Ukraine, the ongoing political turmoil leads to negative impacts on the tourism industry with decreased revenues, plummeting numbers of tourists and overnight stays, and increased costs (Ivanov et al., 2017). In Indonesia, an important study on how small tourism firms have operated during a volatile decade shows the importance of flexibility and diverse income streams that are not limited to tourism (Dahles \& Susilowati, 2015). Despite these studies, the literature lacks studies that evaluate how MENA tourism firms, especially at the firm level, have responded to the ongoing instability and conflict in the region, which provides the context for our research. We mainly focused on the literature on tourism in the Middle East and North African region because we noted that, unlike developed countries and Southeast Asia, a great number of crises in developing countries, especially in the Middle East and North Africa, involve uprisings, revolutions, wars, political instability, civil unrest and security problems. Surprisingly, in the Middle East and North Africa, the picture remains unclear, and the research gap is still immense, as there is not sufficient research on how tourism organisations respond to such crises. Even at the international level, it is rare to use dynamic capabilities to understand tourism organisations' responses.

\section{METHODOLOGY}


This study is conducted within the interpretivist paradigm because the emphasis is on exploring the meaning of the experiences, responses and actions of Libyan tourism managers with regard to the events of the Libyan civil war in 2011 (Casey, 2006). A case study research design is used for two reasons. First, the study focuses on a contemporary phenomenon in its real-life context (Perry, 2001; Yin, 2017). Environmental turbulence is a contemporary and ill-defined event. Thus, there is still a lack of clarity regarding how Libyan tourism firms are able to adapt to such environmental turbulence. Second, the case study methodology is more appropriate for the current paper because the main question that the paper aims to answer is the "how do" rather than "how should" question (Perry, 2001; Yin, 2017). This paper adopts a holistic multiple case study design (Yin, 2017), as the diversity of cases increases the confidence in any common results that might emerge as the evaluation unfolds (Carden, 2009).

\subsection{Sampling}

A multiple case study research design normally selects between six and eight case studies to provide a good understanding of the phenomenon and achieve reliable results (Eisenhardt, 1989). This paper used a criterion-based selection method (LeCompte, Preissle, \& Tesch, 1993) to sample eight tourism firms from the Libyan tourism sector. These eight Libyan tourism firms were purposively selected by applying three criteria. First, the tourism firm should show clear signs of taking reactive action in response to environmental turbulence. This criterion was fulfilled by telephone conversations with tourism managers to identify suitable firms. The second criterion is a willingness to participate in the study, and the third criterion is the availability of and access to secondary 
data to provide corroborating evidence to support the interviews with the managers. By applying these three criteria, eight tourism firms are selected from 166 tourism firms registered with the Libyan Tourism Ministry (LBTS, 2010) at the start of the study in 2014 that survived the initial civil war and ongoing crisis.

In addition, a diversity of tourism organisation types is sought. The primary logic behind this criterion is that a diversity of case studies within the tourism sector strengthens the analysis, especially when the same result is observed across a multiplicity of situations and contexts (Snow, Morrill, \& Anderson, 2003; Yin, 2017). Table 1 presents the eight case studies.

Insert Table 1 about here

\subsection{Data collection}

Data were collected with the approval from the University's Human Research Ethics Committee. The researchers planned to conduct case studies on the ground in Libya using face-to-face meetings. However, the ongoing armed conflict prevented travel to the country, and the researchers conducted the interviews via telephone and Skype instead and asked for documents to be posted online or emailed. Contacts on the ground (academic colleagues and family members) in Libya facilitated access to the documents. As shown in Table 1, the data collection included 20 semi-structured telephone and Skype interviews (Panneerselvam, 2004) with CEOs, deputy CEOs, managers and employees at the eight firms who were selected by a reputational sampling method (LeCompte et al., 1993). The identified participant from each tourism firm participated in interviews lasting approximately 50 minutes to one hour either by telephone or by Skype, depending on the 
availability of technology. All the semi-structured interviews were conducted during the period from August 2013 to March 2014. The participants were questioned about their firm before the civil war, during the initial stages of the war and during the ongoing unrest after the death of Gaddafi. The participants were initially interviewed, with many follow-up phone calls and emails to clarify the data over the data collection period. The researchers sought to limit social desirability bias by ensuring anonymity for the interviewees (Maryon $\&$ Bruner, 2000). The interviews were supplemented by email correspondence to clarify additional points, reviews of the firms' websites and the collection of documents, such as annual reports, meeting minutes and internal reports, to triangulate the data sources and provide a more complete picture of each case (Eisenhardt, 1989). The data focuses on tourism firm's survival during and after the crisis and survival was often required to protect existing firm's physical resources and employees, especially during the civil war. There was very limited information on the customer base of Libyan tourism organizations', because the majority of firms lost their traditional customer base due to the lack of international tourists' arrival.

\subsection{Data analysis}

The interviews were recorded and transcribed verbatim into Arabic (the language of the interviews), translated into English and then reviewed independently by a third reviewer to ensure reliability in the translation process (Brislin, 1980). Interview transcripts were sent to the interviewees to seek their verification and feedback to increase the credibility of the study through respondent validation (Eisenhardt, 1989; Yin, 2017). Additional short 
telephone and Skype interviews were conducted with seven interviewees to clarify issues related to the interview transcripts.

The interview transcripts and secondary data were uploaded into NVivo Version 10 and analysed using template analysis (King, 2004). Template analysis was selected because the hierarchical organisation of the codes enabled the researchers to employ a process to track, identify and cluster specific processes (i.e., responses) that were embedded in the qualitative data. Template analysis combines deductive and inductive approaches to the thematic analysis of data by first developing a template for data analysis with a few predefined codes, which helps guide the analysis and allows new themes to emerge from the data. King (2004) suggests that one of the best ways to construct the initial template is via interview questions.

The initial template was revised, and for this stage, a two-cycle coding process was adopted (Saldaña, 2009). In the first cycle, descriptive coding and In Vivo coding methods were used to transform the interview transcripts and secondary data into meaningful units of information. In the second cycle, pattern coding and axial coding methods were utilised to synthesise similar units of information into analogous lower order processes, which in turn were grouped into similar higher order components. The rational explanations of the tourism crisis and dynamic capability perspective were then used to consolidate similar higher order components into a specific capability. The two-cycle coding process was used in conjunction with modifying the initial template through insertion, deletion and change (King, 2004). The coding was initially conducted by one researcher and then checked by other members of the team for consistency (Saldaña, 2009). 
The template analysis revealed that the firms conformed to a common pattern in their responses. The common pattern could be attributed to the Libyan social context. For example, the subcategory "employee participation" plays a role in both the crisis assessment and crisis response in all the firms, which is likely correlated to the importance of social ties in Libyan society. However, the template analysis showed differences in the firms' responses. For example, firm-E responded to a crisis by selling off all its business assets and completely abandoning its activities, while firm-F used implemented uninterrupted business actions, meaning the hotel continued its ongoing operations during the war to ensure that the hotel could maintain its operations throughout the war.

\section{FINDINGS}

The findings are based on the tourism firms' responses from the interviews, which were supported by secondary data. The findings show that tourism firms were able to survive during the Libyan crisis by developing dynamic capabilities, which are referred to as crisis management capabilities in this paper. Specifically, the results show that Libyan tourism firms developed a set of adaptive capabilities by undertaking reactive actions to the unexpected crisis in 2011. These adaptive capabilities demonstrate a specific type of organisational capability: crisis management capability. This capability consists of two components: crisis assessment and crisis response. The crisis assessment component is based on access to external sources of information with the purpose of collecting and analysing information during the crisis to determine risks and establish a cooperative relationship between a firm's employees and management and external agents. The second component enabled the firms to develop operational responses to these risks. Regarding 
both components, a successful outcome for the firm was based on participation and cooperation between employees and managers.

\subsection{Crisis management capabilities}

Table 2 presents the final template for the data analysis and the two components of crisis management capability, which are associated with identifying potential risks from the crisis and protecting the firm's resources from such risks. The following sections provide details about each component.

Insert Table 2 here

\subsubsection{Crisis assessment}

The findings reveal that at the beginning of the Libyan civil war in 2011, there was close communication between top level management and employees. This communication consisted of formal and informal meetings, telephone conversations and other contacts, which involved discussing the issues of civil unrest. For example, all the employees of firm-D were in direct communication with each other to immediately implement a plan to protect the firm and its assets. As one interviewee said,

"We were in constant contact during the first three days of the revolution in order to find out what is happening and what might be happening to the company, like theft or armed attack or robbery. So, my main responsibility was to keep in constant contact with most employees, and we have held regular meetings in Benghazi about how to protect the firm's assets" [CEO-Interviewee-D1]. 
In addition, as shown in Table 2, the interview data reveal the analytic processes that each firm engaged in, including consultation and discussion, as the managers and employees participated in an examination of the situation in February 2011. For example, in meeting minutes from firm-D dated 16 February 2011, there were discussions between the management and employees about the civil unrest and demonstrations in Benghazi and the potential risks to the firm. These discussions resulted in identifying potential risks associated with the Libyan civil war period; an obvious example was car thefts, which were occurring almost daily during 2011. A sample comment supports this finding:

"Well, actually, we have held three meetings in two days with most employees in order to obtain a clearer picture of the state of the firm and current security in Tripoli. In the light of these meetings, we put forward a plan related to participating employees in protecting the firm's building and cars" [Secretary-Company-Interviewee-A2, 2013].

\subsubsection{Crisis response}

As shown in Table 2, these contacts resulted in the formation of a crisis committee in each case, consisting of top management and employees from each firm's functional areas. For example, as documented in internal meeting minutes and internal correspondence memos from firm-A dated 20/21 February 2011, the CEO held two formal meetings with the firm's staff to assess the circumstances surrounding the firm, suggesting risk-containment mechanisms. In these meetings, it was agreed that a crisis committee should be formed to find ways to protect the firm and its assets. A comment supports this finding:

"The hotel board members decided to form an internal committee with employees from different divisions to protect the hotel and its assets. This was made with the 
cooperation of rebels Anti-government rebels belonging to the National Transitional

Council of Libya (NTC)” [CEO- Interviewee-G1].

The committee was responsible for suggesting and developing mechanisms to address potential risks that might have threatened the firm. For example, email correspondence with the $\mathrm{CEO}$ of firm-C demonstrated that on the first night of the Libyan civil war, the CEO and six employees organised an emergency meeting at the firm's headquarters to assess the crisis. In this meeting, they discussed potential risks, such as a lack of a police presence on the roads leading to El-Alwinat City, and decided to move the firm's operational assets from El-Alwinat City to Tripoli.

In response to risks during the civil war period, in particular vandalism and theft, the tourism firms implemented specific defensive measures. The crisis committee typically assigned the task of protecting the firms' cars and buildings from thieves and vandals to a group of employees participating in guard duties. Moreover, the crisis committee recruited a number of qualified persons to help in the protection processes. For example, the CEOs of tourism firm-A and firm-G recruited rebels belonging to the National Transition Council (NTC) through the help of a third-party mediator. The employees and rebels played a significant role in protecting the buildings and preventing thefts or damage.

As shown in Table 2, the other response was to move all the firm's movable assets and operational resources from the place of danger to a secure warehouse or other safe location. For example, in firm-D’s meeting minutes dated 16 February 2011 between the management and employees, the management decided to assign eight employees with the task of transferring all movable assets, including three cars, six personal computers and 
important documents, to Shahat City and evacuating the entire firm's headquarters in Benghazi. As one interviewee said,

“(...) we all agreed to transport all moveable properties and equipment to a safe place in Tripoli until the situation has calmed down" [CEO-Interviewee-C1, Email Correspondence, 2014].

As shown in Table 2, the last response was to reduce costs, especially operational costs, by shutting down most of the firms' operations. Some tourism firms reduced their direct costs by laying off employees for a temporary period of time because they did not have enough money to pay them, while other tourism firms stopped paying their

employees' wages for a period. Notably, the employees involved in protecting assets were not laid off. Two reports for 2011 and 2012 from firm-H revealed that the firm reduced all employees' wages, which were subject to tax, and reduced the maintenance and depreciation of hotel buildings by considering ways in which it could lower their depreciation expenses.

Overall, the results revealed that the interviewed Libyan tourism firms focused on developing and implementing a set of operational procedures associated with assessing potential risks and then protecting their firms' resources from these potential risks. Such operational procedures represent crisis management capabilities.

\section{DISCUSSION}

This study has shown that to survive the turbulence of the Libyan crisis, successful tourism firms developed dynamic capabilities. Such capabilities include crisis management capabilities, which consist of two components: crisis assessment (cognition) and crisis 
response (behaviour). The crisis assessment component requires strong relationships both internally within a firm via establishing a cooperative relationship between managers and employees as well as externally between the management and its associates outside the firm. These relationships involve collecting and analysing information during the early stages of a crisis to determine the risks facing the firm. The second - behavioural component is aimed at developing operational responses to these risks. For both components, the ongoing interaction and cooperation between employees and managers play key roles in determining and adapting to the identified risks.

Although extensive research has been carried out on tourism crisis management to help tourism managers survive crisis situations (e.g., Bingjie et al., 2015; Hajibaba et al., 2016; Henderson, 2007; Tse et al., 2006), the dynamic capabilities lens has not yet been applied to these situations. The crisis management capabilities developed by the tourism firms in this study primarily reflect the ability of the firms to protect their resources, including their tangible assets, from risks during the crisis period and to reduce their costs so that the firm survives. The importance of ensuring access to resources in enabling tourism firms in developing countries to survive an ongoing crisis has been previously identified (Dahles \& Susilowati, 2015). Specifically, the sample tourism firms reacted defensively in response to the turbulent conditions during the crisis event. Thus, the crisis management capabilities support the reactive approach of crisis management to limit damage during a crisis (Eccles, Newquist, \& Schatz, 2007).

The practical actions associated with crisis management capabilities are consistent with the existing tourism crisis and disaster frameworks (Becken \& Hughey, 2013; Faulkner, 2001; Ritchie, 2004). In particular, the crisis assessment and crisis response 
components are consistent with the actions of the crisis response phase in the 4Rs model (i.e., reduction, readiness, response and recovery) (Becken \& Hughey, 2013), the crisis event stages model (i.e., pre-crisis, crisis event, and post-crisis) (Paraskevas \& Arendell, 2007), and the emergency phase in the tourism disaster-management framework (Faulkner, 2001; Ritchie, 2004). For example, the crisis assessment and crisis response components are equivalent to the emergency response implementation of tourism crisis plans during immediate crisis periods in many existing tourism and disaster models. The way in which Libyan tourism firms responded to the initial crisis was similar to the recommended response to a one-off crisis, which is not surprising, as the length of the crisis was unknown at the start.

This paper contributes new knowledge by providing novel reactive measures and actions for the crisis response phase of the 4Rs model (e.g., Faulkner, 2001; Ritchie, 2004). These new measures, termed information collection and analysis by employee participation and a crisis committee, refer to the ability of both managers and employees to obtain and share key information during the early phase of a crisis. Similarly, the responses by participation and recruitment and responses by transference and reduction measures enable the firms to protect their assets and to survive the crisis. All of these measures are heavily dependent on a firm's human resources and employees' commitment to the firm, sometimes by personally protecting the firm's assets from theft or damage.

To date, there has been limited discussion in the literature regarding how the participation of employees can affect response processes during a crisis period. The findings in this study reveal that the participation of employees during the crisis event played a significant role in determining the risks facing the firm, as well as in designing and 
implementing reactive responses. Notably, many employees either lost their jobs temporarily or were required to work without pay for periods of time, which increased the personal sacrifice that they made for the firm's survival. This willingness to make personal sacrifices can be understood in the context of the importance of tourism to individuals' livelihoods (Dahles \& Susilowati, 2015) but remains largely overlooked by the wider tourism crisis literature. The voluntary participation of human resources during the crisis was the main mechanism in both the crisis assessment and crisis response components of the crisis management capability. The findings of this study indicate that a firm's human resources are the key component of the crisis management capability and therefore the firm's ability to survive.

We argue that crisis management capabilities are rooted in the dynamic capabilities of firms. Indeed, dynamic capabilities allow a firm to renew itself by creating new or modifying existing values and operating capabilities (Breznik \& Hisrich, 2014; Winter, 2003). In responding to a crisis, firms' management demonstrates multiple dynamic capabilities through adaptation and the creation of new business activities that result in the crisis management capability. These findings are in line with the call for research on crisis preparedness and disaster-management strategies (Mair et al., 2016) and provide a better understanding of firms' responses to disastrous events. Furthermore, the current findings confirm that crisis management capabilities have resulted from the creation of a new set of operational responses that enabled tourism firms to assess their potential risks and protect the firms' assets during the crisis event. Thus, adapting to a new environment by creating a new set of multiple operational responses results in a dynamic capability (Winter, 2003). 


\section{CONCLUSION}

We make two theoretical contributions to the literature. First, we extend the existing knowledge on firms' adaptation and responses to an ongoing crisis, underpinning the role of dynamic capabilities in a turbulent environment. Our findings indicate that the dynamic capabilities lens, which has previously not been applied to tourism crises, facilitates an understanding of how firms adapt to and survive in a turbulent environment. The findings reveal that surviving firms that were still operating in 2014 developed new dynamic capabilities, which we term crisis management capabilities. These capabilities enabled the tourism firms to protect their resources from being destroyed during the war, which ensured the firms' survival. The crisis management capabilities identified in this context include two major components, specifically, crisis assessment and responses to risks by undertaking certain measures. Both components of the crisis management capability are highly dependent on a close interaction between the management team and the employees. This paper also expands the crisis management literature by focusing on the individual firm level, which has rarely been studied.

A second theoretical contribution of the study includes the importance of ongoing employee engagement and participation during a crisis. Specifically, the study shows that the employees played a significant role in determining risks and designing and implementing reactive responses to the crisis. Thus, the voluntary participation of human resources during the crisis event and the willingness to make significant personal sacrifices, such as working without pay and personally protecting the firm's assets, are a major component of crisis management capabilities. 
From a practical perspective, the importance of ongoing employee engagement and participation during a crisis reflects a type of cooperative organisational culture. Thus, the policy makers of tourism firms must seek to enhance the cooperative organisational culture by providing intangible stimulants and incentives, such as recognition of the importance of collective group culture and greater employee participation during the crisis event, training opportunities, career development, praise and certificates, as well as financial incentives.

Because the interviewed tourism firms' CEOs managed to quickly establish and execute a set of reactive actions in response to the unanticipated armed conflict, they must recognise the crisis events as an opportunity to analyse and utilise their crisis experiences and newly gained knowledge as an organisational learning basis for developing specific proactive crisis management competencies. That is, the policy makers in the tourism firms must create and dedicate a set of operational routines to carefully monitor the post-civil war circumstances to recognise a potential crisis and then make attempts to avoid or at least minimise the consequences of the potential crisis.

While this paper makes several contributions to the existing crisis management literature, there are limitations inherent in the paper that should be acknowledged. The first limitation is that since this paper has been limited to the context of Libyan tourism firms, the findings may not apply to tourism firms in other countries. In particular, employees in other countries or cultures may be less willing to provide such a commitment to their firms. A second limitation is that the research team was unable to conduct the fieldwork in situ due to the dangerous ongoing situation in Libya, and there were challenges in gathering detailed data using the telephone and Skype interview techniques. The research team needed to make several phone calls to collect in-depth data; however, some interviewees 
refused to engage in follow-up conversations. This is a natural obstacle in conducting research in a crisis environment. The third limitation is that a detailed analysis of Libyan tourism organizations' customer base is beyond the scope of this article because the tourism organizations lost their customer base during the civil war period. Thus, the main aim of this study was to understand firm's survival during the civil war and to identify organizational capabilities that enabled firms to achieve it. Survival required to save firm's assets, such as buildings, vehicles, camps, computers, documents, furniture, and employees. Firms developed specific capabilities to protect resources from being physically destroyed. Looking for new customers was important to firms at much later stages of crisis recovery but these activities were beyond the scope of this study. Similarly, organizational capabilities that enabled firms to resume their business operations or to adapt to the new conditions in the post-crisis stage in 2012 were also beyond the scope of the current study. This focus (i.e., on capabilities that enable business resumption or restoring firm's customer base) is calling for future studies.

Both the use of the dynamic capability lens and the important role that human capital plays in supporting firms during a crisis offer opportunities for further study. Following the crisis management dynamic capability identified in this study, future research could investigate the role of organisational learning in developing proactive crisis management strategies. Additional studies could examine how individual firms, which are typically small enterprises, cope with ongoing turbulence in different cultural settings. Finally, the contribution and experience of the employees before, during and after a crisis and their commitment to the firm needs further exploration. 



\section{References}

Afonso-Rodríguez, J. A. (2017). Evaluating the dynamics and impact of terrorist attacks on tourism and economic growth for Turkey. Journal of Policy Research in Tourism, Leisure and Events, 9(1), 56-81. https://doi.org/10.1080/19407963.2016.1231196

Avraham, E. (2015). Destination image repair during crisis: Attracting tourism during the arab spring uprisings. Tourism Management, 47, 224-232. https://doi.org/10.1016/j.tourman.2014.10.003

Babelytè-Labanauskè, K., \& Nedzinskas, $\breve{S}$. (2017). Dynamic capabilities and their impact on research organizations' R\&D and innovation performance. Journal of Modelling in Management, 12(4), 603-630. https://doi.org/10.1108/JM2-05-2015-0025

Backer, E., \& Ritchie, B. W. (2017). VFR travel: A viable market for tourism crisis and disaster recovery? International Journal of Tourism Research, 19(4), 400-411. https://doi.org/10.1002/jtr.2102

Barney. (1991). Firm resources and sustained competitive advantage. Journal of Management, 17 (1), 99-120.

Becken, S., \& Hughey, K. F. (2013). Linking tourism into emergency management structures to enhance disaster risk reduction. Tourism Management, 36, 77-85. https://doi.org/10.1016/j.tourman.2012.11.006

Beirman, D. (2003). Restoring tourism destinations in crisis: A strategic marketing approach. Australia: Allen \& Unwin.

Beirman, D. (2009). Crisis and post-crisis tourism destination recovery marketing strategies. In C. Pforr and P. Hosie (Eds.), Crisis management in the tourism industry: Beating the odds? (pp. 37-52). Aldershot: Ashgate. 
Bingjie, L., Pennington-Gray, L., \& Klemmer, L. (2015). Using social media in hotel crisis management: The case of bed bugs. Journal of Hospitality and Tourism Technology, 6(2), 102-112. https://doi.org/10.1108/JHTT-08-2014-0036

Blackman, D., \& Ritchie, B. (2008). Tourism crisis management and organizational learning: The role of reflection in developing effective DMO crisis strategies. Journal of Travel \& Tourism Marketing, 23(2-4), 45-57. https://doi.org/10.1300/J073v23n02_04

Boukas, N., \& Ziakas, V. (2013). Impacts of the global economic crisis on cyprus tourism and policy responses. International Journal of Tourism Research, 15(4), 329-345. https://doi.org/10.1002/jtr.1878

Breznik, L., \& Hisrich, R. D. (2014). Dynamic capabilities vs. innovation capability: Are they related? Journal of Small Business and Enterprise Development, 21(3), 368384. https://doi.org/10.1108/JSBED-02-2014-0018

Brislin, R. W. (1980). Translation and content analysis of oral and written materials. In H. W. Triandis and J. W. Berry (Eds.), Handbook of crosscultural psychology: Vol. 2. Methodology (pp. 389-444). Boston: Allyn \& Bacon.

Camisón, C., \& Monfort-Mir, V. M. (2012). Measuring innovation in tourism from the schumpeterian and the dynamic-capabilities perspectives. Tourism Management, 33(4), 776-789. https://doi.org/10.1016/j.tourman.2011.08.012

Canty, M. (2011). Arab spring is "unique opportunity" for tourism. Retrieved from http://www.hoteliermiddleeast.com/13071-arab-spring-is-unique-opportunity-fortourism/\#.Utk-c_SwqIU 
Carden, F. (2009). Knowledge to policy: Making the most of development research. London: SAGE Publications.

Casey, D. (2006). Choosing an appropriate method of data collection. Nurse Researcher, 13(3), 75-92. https://doi.org/10.7748/nr2006.04.13.3.75.c5980

Chen, M.-H. (2011). The response of hotel performance to international tourism development and crisis events. International Journal of Hospitality Management, 30(1), 200-212. https://doi.org/10.1016/j.ijhm.2010.06.005

Dahles, H., \& Susilowati, T. P. (2015). Business resilience in times of growth and crisis. Annals of Tourism Research, 51, 34-50. https://doi.org/10.1016/j.annals.2015.01.002

del Mar, A.-A. M., \& Bremser, K. (2013). Strategic responses of the Spanish hospitality sector to the financial crisis. International Journal of Hospitality Management, 32, 141-148. https://doi.org/10.1016/j.ijhm.2012.05.004

Stefano, D., Peteraf, M., \& Gianmario, V. (2010). Dynamic capabilities deconstructed: a bibliographic investigation into the origins, development and future directions of the researh domain. Industrial and corporate Change, 19 (3), 1187-1204.

Easterby-Smith, M., Lyles, M. A., \& Peteraf, M. A. (2009). Dynamic capabilities: Current debates and future directions. British Journal of Management, 20(S1). https://doi.org/10.1111/j.1467-8551.2008.00609.x

Eccles, R. G., Newquist, S. C., \& Schatz, R. (2007). Reputation and its risks. Harvard Business Review, 85(2), 104-114.

Eisenhardt, K. M. (1989). Building theories from case study research. Academy of Management Review, 14(4), 532-550. https://doi.org/10.5465/amr.1989.4308385 
Eisenhardt, K. M., \& Martin, J. A. (2000). Dynamic capabilities: What are they? Strategic Management Journal, 21(10-11), 1105-1121. https://doi.org/10.1002/10970266(200010/11)21:10/11<1105::AID-SMJ133>3.0.CO;2-E

Elshaer, I. A., \& Saad, S. K. (2017). Political instability and tourism in Egypt: Exploring survivors' attitudes after downsizing. Journal of Policy Research in Tourism, Leisure and Events, 9(1), 3-22. https://doi.org/10.1080/19407963.2016.1233109

Faulkner, B. (2001). Towards a framework for tourism disaster management. Tourism Management, 22(2), 135-147. https://doi.org/10.1016/S0261-5177(00)00048-0

Fick, D. (2007). Africa: Continent of economic opportunity. South Africa: STE Publishers.

Frank, H., Güttel,W., \& Kessler, A. (2017). Environmental dynamism, hostility, and dynamic capabilities in medium-sized enterprises, The International Journal of Entrepreneurship and Innovation, 18 (3), 185-194.

https://doi.org/10.1177/1465750317723219

Girod, S. J., \& Whittington, R. (2017). Reconfiguration, restructuring and firm performance: Dynamic capabilities and environmental dynamism. Strategic Management Journal, 38(5), 1121-1133. https://doi.org/10.1002/smj.2543

Gkritzali, A. (2017). Online destination sentiment recovery during a sustained crisis. Annals of Tourism Research, 66, 183-185. https://doi.org/10.1016/j.annals.2017.05.012

Hajibaba, H., Boztuğ, Y., \& Dolnicar, S. (2016). Preventing tourists from canceling in times of crises. Annals of Tourism Research, 60, 48-62. https://doi.org/10.1016/j.annals.2016.06.003 
Henderson, J. C. (2007). Corporate social responsibility and tourism: Hotel companies in Phuket, Thailand, after the Indian ocean tsunami. International Journal of Hospitality Management, 26(1), 228-239.

https://doi.org/10.1016/j.ijhm.2006.02.001

Irvine, W., \& Anderson, A. R. (2004). Small tourist firms in rural areas: Agility, vulnerability and survival in the face of crisis. International journal of entrepreneurial behaviour \& research, 10(4), 229-246.

https://doi.org/10.1108/13552550410544204

Ivanov, S., Gavrilina, M., Webster, C., \& Ralko, V. (2017). Impacts of political instability on the tourism industry in Ukraine. Journal of Policy Research in Tourism, Leisure and Events, 9(1), 100-127. https://doi.org/10.1080/19407963.2016.1209677

King, N. (2004). Using templates in the thematic analysis of texts. In C. Cassell and G. Symon (Eds.), Essential guide to qualitative methods in organizational research (pp. 256-270). London: SAGE Publications.

KPMG. (2014). Investing in Libya. KPMG: United accountants for professional services llc. Retrieved from https://www.kpmg.com/LY/en/IssuesAndInsights/Research/Documents/Investingin-Libya.pdf

Lanquar, R. (2012). Tourism in the mediterranean: Scenarios up to 2030. Medpro report No. 1. Brussels: CEPS.

Lanquar, R. (2015). Tourism in the mediterranean. In R. Ayadi, M. Dabrowski and L. D. Wulf (Eds.), Economic and social development of the southern and eastern mediterranean countries (pp. 111-126). Switzerland: Springer. 
LBTS. (2010). Statistics of travel and tourism industry: Libyan Bureau of Tourism Statistics.

LeCompte, M. D., Preissle, J., \& Tesch, R. (1993). Ethnography and qualitative design in educational research. San Diego: Academic Press.

Leonidou, L. C., Leonidou, C. N., Fotiadis, T. A., \& Aykol, B. (2015). Dynamic capabilities driving an eco-based advantage and performance in global hotel chains: The moderating effect of international strategy. Tourism Management, 50, 268-280. https://doi.org/10.1016/j.tourman.2015.03.005

Lessard, D., Teece, D. J., \& Leih, S. (2016). Introduction to special topic forum on developing the dynamic capabilities of global companies across levels and locations. Global Strategy Journal, 6(3), 165-167. https://doi.org/10.1002/gsj.1120

Mair, J., Ritchie, B., \& Walters, G. (2016). Towards a research agenda for post-disaster and post-crisis recovery strategies for tourist destinations: A narrative review. Current Issues in Tourism, 19(1), 1-26. https://doi.org/10.1080/13683500.2014.932758

Mansour, H. E. (2016). Firms adaptation to environmental turbulence: The case of the Libyan tourism sector (Doctoral dissertation, Curtin University, Curtin). Retrieved from http://hdl.handle.net/20.500.11937/196

Maryon, K. F., \& Bruner, G. C. (2000). Social desirability bias: A neglected aspect of validity testing. Psychology and Marketing, 17(2), 79-103. https://doi.org/10.1002/(SICI)1520-6793(200002)17:2<79::AID-MAR2>3.0.CO;20 
Morakabati, Y. (2013). Tourism in the middle east: Conflicts, crises and economic diversification, some critical issues. International Journal of Tourism Research, 15(4), 375-387. https://doi.org/10.1002/jtr.1882

Nonaka, I. (1994). A dynamic theory of organizational knowledge creation. Organization Science, 5(1), 14-37. https://doi.org/10.1287/orsc.5.1.14

Nonaka, I., Hirose, A., \& Takeda, Y. (2016). 'Meso'-foundations of dynamic capabilities: Team-level synthesis and distributed leadership as the source of dynamic creativity. Global Strategy Journal, 6(3), 168-182. https://doi.org/10.1002/gsj.1125

Orchiston, C., Prayag, G., \& Brown, C. (2016). Organizational resilience in the tourism sector. Annals of Tourism Research, 56, 145-148. https://doi.org/10.1016/j.annals.2015.11.002

Otengei, S. O., Bakunda, G., Ngoma, M., Ntayi, J. M., \& Munene, J. C. (2017). Internationalization of African-ethnic restaurants: A qualitative enquiry using the dynamic capabilities perspective. Tourism Management Perspectives, 21, 85-99. https://doi.org/10.1016/j.tmp.2016.12.001

Panneerselvam, R. (2004). Research methodology. New Delhi: PHI Learning.

Paraskevas, A., \& Arendell, B. (2007). A strategic framework for terrorism prevention and mitigation in tourism destinations. Tourism Management, 28(6), 1560-1573. https://doi.org/10.1016/j.tourman.2007.02.012

Perry, C. (2001). Case research in marketing. Marketing Review, 1(3), 303-323. https://doi.org/10.1362/1469347002530790 
Pforr, C., \& Hosie, P. J. (2008). Crisis management in tourism: Preparing for recovery. Journal of Travel \& Tourism Marketing, 23(2-4), 249-264. https://doi.org/10.1300/J073v23n02_19

Protogerou A., Caloghirou Y., \& Lioukas S. (2012). Dynamic Capabilities and their indirect impact on firm performance, Industrial and Corporate Change, 21 (3),

Ritchie, B. (2004). Chaos, crises and disasters: A strategic approach to crisis management in the tourism industry. Tourism Management, 25(6), 669-683. https://doi.org/10.1016/j.tourman.2003.09.004

Ritchie, B., Dorrell, H., Miller, D., \& Miller, G. A. (2004). Crisis communication and recovery for the tourism industry: Lessons from the 2001 foot and mouth disease outbreak in the United Kingdom. Journal of Travel \& Tourism Marketing, 15(2-3), 199-216. https://doi.org/10.1300/J073v15n02_11

Roach, J., \& Kemish, I. (2006). Bali bombings: A whole of government response. In J. Wilks, D. Pendergast and P. Leggat (Eds.), Tourism in turbulent times: Towards a safe experience for visitors (pp. 277-289). Oxford: Elsevier.

Ruiz-Ortega, M., Parra-Requena, G., Rodrigo, J., Garcia-Villaverde, P. M. (2013). Environmental dynamism and entrepreneurial orientation: The moderating role of firm's capabilities. Journal of Organizational Change Management 26(3), 475-493, DOI: $10.1108 / 09534811311328542$

Saldaña, J. (2009). The coding manual for qualitative researchers. London: SAGEPublications Ltd. 
Santana, G. (2004). Crisis management and tourism: Beyond the rhetoric. Journal of Travel \& Tourism Marketing, 15(4), 299-321. https://doi.org/10.1300/J073v15n04_05

Schilke, O. (2014). On the contingent value of dynamic capabilities for competitive advantage: the nonlinear moderating effect of environmental dynamism. Strategic Management Journal, 35(2), 179-203.

Schilke, O., Hu, S., \& Helfat, C. (2018). Quo vadis, dynamic capabilities? Academy of Management Annals, 12(1), 390-439

Snow, D. A., Morrill, C., \& Anderson, L. (2003). Elaborating analytic ethnography linking fieldwork and theory. Ethnography, 4(2), 181-200. https://doi.org/10.1177/14661381030042002

Tchuta, L., \& Xie, F. (2017). Towards a synergic innovation management model: The interplay of market, technology, and management innovations. International Journal of Business and Economic Development (IJBED), 5(1), 60-70.

Teece, D. J. (2007). Explicating dynamic capabilities: The nature and microfoundations of (sustainable) enterprise performance. Strategic Management Journal, 28(13), 13191350. https://doi.org/10.1002/smj.640

Teece, D. J. (2014). A dynamic capabilities-based entrepreneurial theory of the multinational enterprise. Journal of International Business Studies, 45(1), 8-37. https://doi.org/10.1057/jibs.2013.54

Teece, D. J., Pisano, G., \& Shuen, A. (1997). Dynamic capabilities and strategic management. Strategic Management Journal, 18(7), 509-533. https://doi.org/10.1002/(SICI)1097-0266(199708)18:7<509::AIDSMJ882>3.0.CO;2-Z 
Tse, A. C. B., So, S., \& Sin, L. (2006). Crisis management and recovery: How restaurants in Hong Kong responded to SARS. International Journal of Hospitality Management, 25(1), 3-11. https://doi.org/10.1016/j.ijhm.2004.12.001

UNWTO. (2012). UNWTO tourism highlights 2012 edition. Retrieved from http://mkt.Unwto.Org/sites/all/files/docpdf/unwtohighlights12enhr.Pdf

UNWTO. (2013). UNWTO tourism highlights 2014 edition. Retrieved from http://dtxtq4w60xqpw.Cloudfront.Net/sites/all/files/pdf/unwto_highlights14_en.Pdf

UNWTO. (2014). UNWTO tourism highlights 2014 edition. Retrieved from http://dtxtq4w60xqpw.Cloudfront.Net/sites/all/files/pdf/unwto_highlights14_en.Pdf

Vogel, R., \& Güttel, W. H. (2013). The Dynamic Capability View in Strategic Management: A Bibliometric Review. International Journal of Management Reviews, 15, 426-446. DOI: 10.1111/ijmr.12000

WEF. (2012). The global competitiveness report: Libya. 2011-2012 the world economic forum, Geneva, Switzerland. Switzerland: WEF.

Wilden, R., \& Gudergan, S. (2017). Service-dominant orientation, dynamic capabilities and firm performance. Journal of Service Theory and Practice, 27(4), 808-832. https://doi.org/10.1108/JSTP-04-2016-0077

Winter, S. G. (2003). Understanding dynamic capabilities. Strategic Management Journal, 24(10), 991-995. https://doi.org/10.1002/smj.318

WTTC. (2017). Travel \& tourism economic impact: Libya. London: WTTC.

Yin, R. K. (2017). Case study research and applications: Design and methods. Thousand Oaks: Sage Publications. 


\section{TABLES}

Table 1. Characteristics of the eight selected case studies

\begin{tabular}{|c|c|c|c|}
\hline $\begin{array}{l}\text { Firm } \\
\text { Name }\end{array}$ & Description & $\begin{array}{l}\text { Interview } \\
\text { Participants }\end{array}$ & $\begin{array}{l}\text { Number of } \\
\text { Interviews }\end{array}$ \\
\hline A & $\begin{array}{l}\text { Firm-A was founded in 2004, headquartered in Tripoli and } \\
\text { employed } 35 \text { employees. The main focus of the firm's operations } \\
\text { was on Sahara adventure and heritage site tours. }\end{array}$ & $\begin{array}{l}\text { 1- CEO } \\
\text { 2- Company-Secretary }\end{array}$ & 2 \\
\hline B & $\begin{array}{l}\text { Firm-B was founded in 1996, located in Tripoli and employed } 10 \\
\text { employees. The firm operated in the pilgrimage tourism field. }\end{array}$ & $\begin{array}{l}\text { 1- CEO } \\
\text { 2- CEO-Deputy } \\
\text { 3- Employee }\end{array}$ & 3 \\
\hline C & $\begin{array}{l}\text { Firm-C was founded in 1998, located in Tripoli and employed } 16 \\
\text { employees. The firm operated camel riding and 4WD trips in the } \\
\text { Libyan Sahara. }\end{array}$ & $\begin{array}{l}\text { 1- CEO } \\
\text { 2- Marketing Director } \\
\text { 3- Employee }\end{array}$ & 3 \\
\hline D & $\begin{array}{l}\text { Firm-D is headquartered in Benghazi City, was founded in } 2000 \text {, } \\
\text { and had } 17 \text { employees. The firm specialised in two tourism } \\
\text { activities. The first was archaeological visits, and the second was } \\
\text { visiting services to the Apollonia Museum (also known as the Susa } \\
\text { Museum). }\end{array}$ & $\begin{array}{l}\text { 1- CEO } \\
\text { 2- CEO-Deputy } \\
\text { 3- Employee }\end{array}$ & 3 \\
\hline $\mathrm{E}$ & $\begin{array}{l}\text { Firm-E was located in Tripoli, founded in } 2000 \text { and had } 13 \\
\text { employees. The firm specialised in offering pre-paid vacations to } \\
\text { archaeological sites in West Libya. }\end{array}$ & $\begin{array}{l}\text { 1- CEO } \\
\text { 2- CEO-Deputy }\end{array}$ & 3 \\
\hline $\mathrm{F}$ & $\begin{array}{l}\text { Firm-F was founded in } 2010 \text { and located in Benghazi. The firm } \\
\text { employed } 2 \text { employees. The firm was authorised by the local } \\
\text { tourism authority in Benghazi to provide tourist visa services, } \\
\text { including the issuing of official invitation letters for tourism } \\
\text { purposes. }\end{array}$ & $\begin{array}{l}\text { 1- CEO } \\
\text { 2- Front-line } \\
\text { Employee }\end{array}$ & 2 \\
\hline $\mathrm{G}$ & $\begin{array}{l}\text { Firm-G was situated in Benghazi City and founded in } 1984 \text {. The } \\
\text { firm was classified as a four-star hotel and employed } 131 \text { staff } \\
\text { employees. The firm offers } 24 / 7 \text { room service and luxurious suites. }\end{array}$ & $\begin{array}{l}\text { 1- CEO } \\
\text { 2- CEO-Deputy } \\
\text { 3- Assistant Manager }\end{array}$ & 3 \\
\hline $\mathrm{H}$ & $\begin{array}{l}\text { Firm-H was a five-star hotel in Tripoli, was managed by the Hotels } \\
\text { International Limited Company located in Malta, and was opened in } \\
\text { 2003. The firm employed } 397 \text { employees, was built purposefully } \\
\text { with the business community in mind, and has since become the } \\
\text { most prestigious venue for business in Libya. }\end{array}$ & $\begin{array}{l}\text { 1- Chief Financial } \\
\text { Officer }\end{array}$ & 1 \\
\hline
\end{tabular}


Table 2. The final template of the crisis management capability

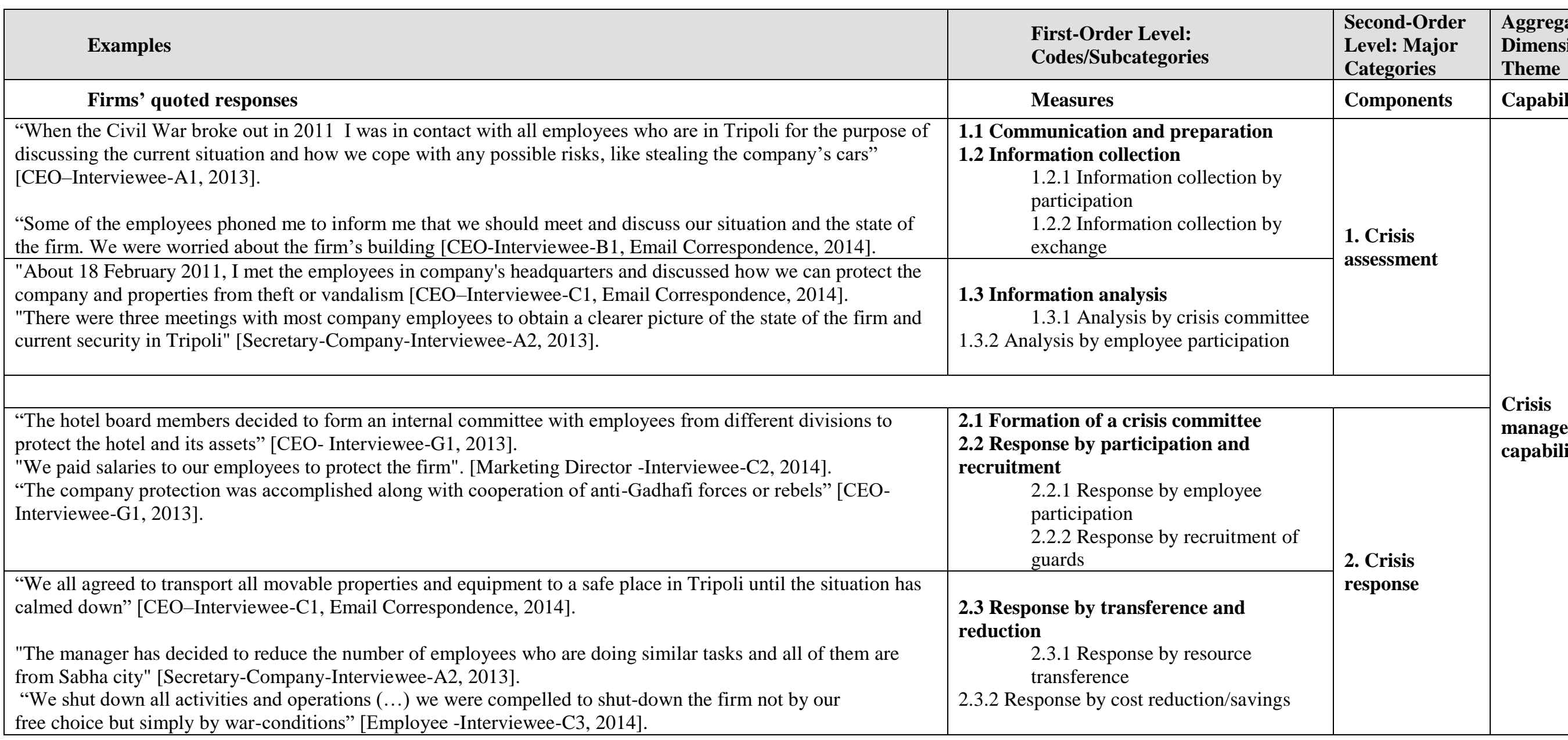

